\title{
ANALISA SWOT PERANCANGAN SISTEM INFORMASI AKADEMIK BERBASIS WEB
}

\author{
Megawati $^{1}, \operatorname{Irman}^{2}$ \\ ${ }^{1,2}$ Program Studi Sistem Informasi, Fakultas Sains dan Teknologi UIN Suska Riau \\ Jl. HR Soebrantas KM.18 Panam Pekanbaru - Riau \\ ${ }^{1}$ megawati@uin-suska.ac.id, \\ ${ }^{2} 11653103394 @$ students.uin-suska.ac.id
}

\begin{abstract}
Abstrak - Analisa SWOT dilakukan untuk menyusun strategi, menganalisa prospek peningkatan kualitas layanan, mengacu pada keadaan sekarang, apakah strategi yang dapat dilakukan pondok kedepan sesuai faktorfaktor penentu dalam metode analisa SWOT. Analisa terbatas hanya pada bagian Tata Usaha. Teknik pengambilan sampel adalah dengan metode purpousive sampling, yaitu dengan menentukan ciri-ciri khusus yang sesuai dengan tujuan penelitian. Hasil analisa menunjukan pelayanan Tata Usaha pondok berada posisi sumbu $+\mathrm{x},+\mathrm{y}$. Yang artinya berada pada kuadran mendukung strategi agresif, yaitu memanfaatkan segala peluang yang ada untuk meningkatkan mutu layanan pada bagian Tata Usaha. Rancangan sistem informasi akademik dengan metode OOAD adalah bentuk pemanfaatna peluang yang ada saat ini, dengan menggunakan metode OOAD
\end{abstract}

Kata Kunci : analisa SWOT, strategi, perancangan, OOAD

\section{PENDAHULUAN}

Untuk mendukung kelancaran proses belajar mengajar pada instansi pendidikan dibutuhkan suatu bagian untuk mendukung kegiatan tersebut yaitu Bagian Ketata usahaan. Tata usaha adalah suatu bagian dari instansi pendidikan yang berfungsi sebagai pendukung kegiatan belajar mengajar agar berjalan sesuai dengan apa yang telah tetapkan agar bisa tercapai seperti apa yang diinginkan.

Menurut Peraturan Menteri Pendidikan Nasional No 24 Tahun 2008 tentang Standar Tenaga Administrasi Sekolah/Madrasah bahwa Pelaksana Urusan Administrasi Sekolah harus memiliki kompetensi teknis sebagai berikut:

a. Melaksanakan Administrasi Kepegawaian

b. Melaksanakan Administrasi Keuangan

c. Melaksanakan Administrasi Sarana dan Prasarana

d. Melaksanakan Administrasi Hubungan Sekolah dengan Masyarakat

Menurut [1], "Pegawai tata usaha berperan penting setidaknya dalam dua hal. Pertama, dalam menentukan mutu kebijakan sekolah. Semakin tepat data yang diberikan oleh tata usaha maka makin tinggi kepuasan. Kedua, peran dalam menentukan mutu layanan sekolah sebagai publik relation sekolah."
Seiring dengan berkembangnya zaman atau sering disebut sebagai era globalisasi, fungsi bagian tata usaha harus lebih dapat ditingkatkan kualitasnya dengan menggunakan berbagai teknologi terutama teknologi informasi ataupun lebih dikenal dengan era komputerisasi. Dengan tujuan untuk meningkatan efektifitas kegiatan serta memberikan pelayanan yang lebih baik. Oleh sebab itu sudah selayaknya setiap staf tata usaha diharuskan menguasai teknologi informasi.

Untuk melakukan penigkatan kualitas pelayanan, sebagai langkah profesional tentu membutuhkan pencermatan terhadap situasi dan kondisi saat ini. Sehingga dalam meraih sebuah tujuan tidak mengorbankan agenda-agenda lain yang tidak kalah pentingnya. Dengan melakukan analisa SWOT dapat diketahui strategi apa yang dapat dilakukan untuk meningkatkan kualitas layanan pada bagian tata usaha.

Faktor-faktor apa yang menjadi kekuatan bagian tata usaha dan peluang apa yang dapat dimanfaatkan untuk meningkatkan kualitas layanan. Serta faktor-faktor apa yang menjadi kelemahan bagian tata usaha dan faktor-faktor apa saja yang menjadi ancaman bagian tata usaha sehingga jika harus di perbaiki.

Analisa ini diharapkan dapat merekomendasikan sebuah strategi bagian tata usaha, apakah dengan menggunakan tekhnologi 
informasi agar performa layanan dapat ditingkatkan ataukah cukup dengan hanya bertahan karena tidak didukung oleh peluang yang menguntungkan. Atau apakah ancaman lebih besar daripada peluang yang ditawarkan jika dipaksakan melakukan perubahan.

Salah satu permasalahan yang dihadapai oleh bagian tata usaha dalam usaha meningkatkan mutu layanan adalah bagaimana mengelola data pada bagian tata usaha sehingga dapat diakses dengan mudah. Data-data disimpan secara terstruktur dan tidak mengandung redudansi, sehingga dapat mengefisienkan waktu dan tenaga.

\section{A. Tata Usaha}

Menurut [1], "Tata usaha sebagai aktivitas administrasi adalah suatu kegiatan untuk mengadakan pencatatan dan penyusunan keterangan-keterangan dengan secara efektif dan efisien dengan menggunakan sarana dan prasarana sehingga keteranganketerangan itu dapat dipergunakan secara langsung sebagai bahan informasi baik bagi pimpinan organisasi yang bersangkutan ataupun dapat dipergunakan oleh pihak luar organisasi yang membutuhkan."

Dari pendapat diatas dapat disimpulkan bahwa tata usaha merupakan bagian penting dari sebuah organisasi yang bertugas untuk mencatat dan mengarsipkan segala bentuk data dan kemudian mengolahnya menjadi informasi yang dapat digunakan. Seiring perkembangan zaman, terutama perkembangaan tekhnologi inofrmasi telah membawa perubahan besar terhadap sistem pengolahan data dan pengarsipan informasi yang awalnya dilakukan secara manual dengan menyimpan arsip-arsip dalam sebuah map dan disimpan dalam rak-rak didalam sebuah ruangan. Saat ini metode penyimpanan demikian sudah dikurangi dengan melakukan penyimpanan secara elektronik. Meskipun disadari bahwa tidak semua arsip dan dokumen yang dapat disimpan secara elektronik. Namun data-data primer biasanya dapat disimpan dalam bentuk elektronik untuk kemudian digunakan dan menghasilkan output berupa informasi tertentu.

\section{B. Analisa SWOT}

Analisa SWOT digunakan untuk merumuskan strategi dalam menghadapi peluang serta ancaman pasar terhadap sebuah produk atau jasa, dengan mengetahui kekuatan dan kelemahan produk atau jasa yang kita miliki.

Menurut [2], "Strategi merupakan alat untuk mencapai tujuan". Sehingga untuk mengetahui strategi apa yang dapat digunakan untuk meningkatkan mutu, dan efektifitas penggunaan sumber daya, diperlukan kajian tentang keadaan saat ini dan strategi apa yang dapat digunakan dengan keadaan tersebut. Terdapat dua konsep yang menentukan suksesnya strategi yang disusun;

a. Distinctive Competence : tindakan yang dilakukan oleh perusahaan agar dapat melakukan kegiatan lebih baik dibandingkan dengan pesaingnya

b. Competitive Advantage : kegiatan spesifik yang dikembangkan oleh perusahaan agar lebih unggul dibandingkan dengan pesaingya. [2]

\section{Sistem}

"Sistem adalah kumpulan dari elemen-elemen yang berinteraksi untuk mencapai suatu tujuan tertentu. Sistem ini menggambarkan suatu kejadian-kejadian dan kesatuan yang nyata, seperti tempat, benda dan orang-orang yang betul-betul ada dan terjadi," (Jogiyanto, 2005).

Analisa sistem dapat didefinisikan sebagai penguraian dari suatu sistem informasi yang utuh kedalam bagian-bagian komponennya dengan maksud untuk mengidentifikasikan dan mengevaluasi permasalahan-permasalahan, kesempatan-kesempatan, hambatan-hambatan yang terjadi dan kebutuhan-kebutuhan yang diharapkan sehingga dapat diusulkan perbaikan-perbaikannya (Jogiyanto, 2005).

\section{Informasi}

Informasi adalah data yang diolah menjadi bentuk yang lebih berguna dan lebih berarti bagi yang menerimanya (Jogiyanto). Data adalah kenyataan yang menggambarkan suatu kejadiankejadian dan kesatuan nyata. Atau data adalah : representasi dunia nyata yang mewakili suatu objek seperti manusia (pegawai, mahasiswa, pelanggan), hewan, peristiwa, konsep, keadaan dll, yang direkam dalam bentuk angka, huruf, simbol, teks, gambar, bunyi atau kombinasinya.

Informasi merupakan salah satu sumber daya yang sangat diperlukan di dalam suatu organisasi (mulianto, Agus. 2009).

\section{E. Sistem Informasi Akademik}

Menurut [3], "Sistem informasi akademik adalah sistem yang mengelola semua aktifitas yang berkaitan dengan kegiatan akademis, seperti proses pembelajaran, tugas, ujian, nilai, pengelolaan siswa dan guru, kelulusan dan alumni."

\section{METODOLOGI PENELITIAN}

Secara garis besar, penulis akan melakukan dua buah analisa yang meliputi analisa strategis dan analisa perancangan sistem informasi. Analisa 
strategis menggunakan pendekatan dengan metode Analisa SWOT.

"Analisa SWOT adalah identifikasi berbagai faktor secara sistematis untuk merumuskan strategi perusahaan," [4].

"Analisi SWOT meliputi factor internal kekuatan (Strenghs) dan kelemahan (Weaknesess) serta factor eksternal yaitu peluang (Opportunity) dan ancaman (Treats), " [5].

Pendekatan perancangan sistem yang digunakan pada penelitian ini adalah object oriented analysis and design (OOAD). Ada tiga buah diagram unified modeling language (UML) yang digunakan, yaitu: (1) usecase diagram; (2) sequence diagram; dan (3) class diagram.

Konsep OOAD mencakup analisis dan desain sebuah sistem dengan pendekatan objek, yaitu analisis berorientasi objek (OOA) dan desain berorientasi objek (OOD). OOA adalah metode analisis yang memerika requirement (syarat/keperluan) yang harus dipenuhi sebuah sistem dari sudut pandang kelas-kelas dan objekobjek yang ditemui dalam ruang lingkup perusahaan. Sedangkan OOD adalah metode untuk mengarahkan arsitektur software yang didasarkan pada manipulasi objek-objek sistem atau subsistem.

\section{A. Perencanaan}

Tahap perencanaan dilakukan untuk mengidentifikasi permasalahan yang terjadi. Tahap ini dilakukan dengan cara wawancara dan observasi. Wawancara dilakukan ke Kepala agian Tata Usaha Pondok Pesantren Al-Uswah dan Mudir Pondok. Observasi dilakukan pada ruang komputer Bagian Tata Usaha. Selain untuk mengindentifikasi masalah dan kebutuhan pengguna, wawancara dan observasi juga menghasilkan data primer dan data sekunder.

\section{B. Kuisioner}

Hasil wawancara dengan para stakeholder pada Pondok Pesantren Al-Uswah, dijadikan sebuah rumusan menggunakan metode Saaty 1-9. untuk memberikan penilaian bobot masing-masing faktor SWOT. Selanjutnya data masing-masing faktor dianalisa dengan menggunakan metode AHP. Nilai rata-rata metrik dijadikan sebagai nilai bobot pada masing-masing faktor.

Untuk memberikan penilaian rating pada internal analisa SW tabel IFAS berdasarkan hasil wawancara faktor-faktor SWOT dijadikan pertanyaan kuisioner dengan memberikan penilaian dalam rentang (1) sedikit penting, (2) agak penting, (3) penting, dan (4) sangat penting. Responden dari kuisioner ini adalah bagian eksternal tata usaha.

Penialaian rating eksternal analisa OT tabel EFAS memiliki rentang nilai antara (4) sedikit penting, (3) agak penting (2) penting dan (1) sangat penting. Dengan responden bagian internal tata usaha

\section{Analisa SWOT}

\section{C.1 Penilaian Bobot Faktor}

Setelah menganalisa priorirty fector bersama-sama dengan Kepala Tata Usaha dan Mudir Pondok, maka didapatkan kepentingan faktor atas faktor-faktor lainnya yang antara lain, faktor Strenghts (kekuatan):

1. Penggunaan Tekhnologi Informasi pada bagian Tata Usaha 6 kali lebih penting dari pada sistem aplikasi gratis

2. Penggunaan Tekhnologi Informasi pada bagian Tata Usaha sama pentingnya daengan kemudahan melakukan penyimpanan

3. Penggunaan Tekhnologi Informasi pada bagian Tata Usaha 0,3 kali lebih penting daripada tools

4. Penggunaan Tekhnologi Informasi pada bagian Tata Usaha 0,7 kali lebih penting daripada kemampuan SDM menggunakan sistem

5. Sistem Aplikasi gartis 0,5 kali lebih penting daripada kemudahan melakukan penyimpanan

6. Sistem Aplikasi gartis 0,5 kali lebih penting dari pada tools

7. Sistem Aplikasi gartis 0,6 kali lebih penting daripada kemampuan SDM menggunakan sistem

8. Kemudahan melakukan penyimpanan 2 kali lebih penting daripada tools

9. Kemudahan melakukan penyimpanan 0,5 kali lebih penting daripada kemampuan SDM menggunakannya

10. Tools 0,6 kali lebih penting daripada kemampuan SDM menggunakan sistem

Faktor Weakness (kelemahan);

1. Tenaga SDM 5 kali lebih penting daripada Kecepatan proses data

2. Tenaga SDM sama pentingnya dengan Prosedur koreksi data nilai

3. Tenaga SDM 3 kali lebih penting daripada struktur penyimpanan data

4. Tenaga SDM 3 kali lebih penting daripada menghindari duplikasi data

5. Kecepatan proses data sama pentingnya dengan Prosedur koreksi data nilai

6. Kecepatan proses data sama pentingnya dengan struktur penyimpanan data

7. Kecepatan proses data 4 kali lebih penting daripada Menghindari duplikasi data

8. Prosedur koreksi data nilai 4 kali lebih penting daripada struktur penyimpanan data 
9. Prosedur koreksi data nilai 3 kali lebih penting daripada Menghindari duplikasi data

10. Struktur penyimpanan data 4 kali lebih penting daripada Menghindari duplikasi data

Faktor Opportunities (peluang)

1. Dukungan Mudir pondok 5 kali lebih penting daripada Adabtasi tenaga dengan sistem

2. Dukungan Mudir pondok sama pentingnya dengan Kebijakan memperkenalkan program-program pondok melalui internet

3. Dukungan Mudir pondok sama pentingnya dengan wacana pembuatan labor komputer

4. Dukungan Mudir pondok 0,33 kali lebih penting daripada Program depag untuk bantuan TI

5. Adabtasi tenaga dengan sistem 0,25 kali lebih penting daripada Kebijakan memperkenalkan program-program pondok melalui internet

6. Adabtasi tenaga dengan sistem sama pentingnya dengan Wacana pembuatan labor komputer

7. Adabtasi tenaga dengan sistem 0,33 kali lebih penting daripada Program depag untuk bantuan TI

8. Kebijakan memperkenalkan programprogram pondok melalui internet 3 kali lebih daripada Wacana pembuatan labor komputer

9. Kebijakan memperkenalkan programprogram pondok melalui internet 2 lebih penting daripada Program depag untuk bantuan TI

10. Wacana pembuatan labor komputer 0,2 lebih baik daripada Program depag untuk bantuan TI

Faktor Treats (ancaman)

1. Arus listrik 4 kali lebih penting daripada Kontrol akses data

2. Arus listrik 0,33 kali lebih penting daripada Keamanan data terhadap penggunaan ilegal

3. Arus listrik 0,2 kali lebih penting daripada Mengatasi transfer virus melalui flashdhisc

4. Arus listrik 0,25 kali lebih penting daripada Kecepatan laporan penilaian guru

5. Kontrol akses data 0,17 kali lebih penting daripada Keamanan data terhadap penggunaan ilegal

6. Kontrol akses data sama pentingnya dengan Mengatasi transfer virus melalui flashdhisc

7. Kontrol akses data 3 kali lebih penting daripada Kecepatan laporan penilaian guru
8. Keamanan data terhadap penggunaan ilegal sama pentingnya dengan Mengatasi transfer virus melalui flashdhisc

9. Keamanan data terhadap penggunaan ilegal 2 kali lebih penting daripada Kecepatan laporan penilaian guru

10. Mengatasi transfer virus melalui flashdhisc 0,25 kali lebih penting daripada Kecepatan laporan penilaian guru

\section{C.2 Metrik Priority vector}

Langkah selanjutnya adalah membuat matrik masing-masing faktor, dan normalisasi metrik. Nilai rata-rata metrik normal diperoleh dengan menjumlahkan baris metrik dan membaginya dengan jumlah data, hasilnya menjadi nilai bobot analisa SWOT. Jika dijumlahkan setiap kolom metrik harus bernilai 1 (satu), jika lebih atau kurang dari satu, lakukan normalisasi lagi hingga menghasilkan nilai satu.

Table 1: Metrik priority vector Strenghts

\begin{tabular}{cccccc}
\hline S & S1 & S2 & S3 & S4 & S5 \\
\hline S1 & 1 & 6 & 1 & 0,33 & 0,14 \\
S2 & 0,17 & 1 & 0,2 & 0,2 & 0,17 \\
S3 & 1 & 5 & 1 & 2 & 0,2 \\
S4 & 3 & 5 & 0,5 & 1 & 0,17 \\
S5 & 7 & 6 & 5 & 6 & 1 \\
\hline Jumlah & 12,17 & 23 & 7,7 & 9,53 & 1,68 \\
\hline
\end{tabular}

Table 2: normalisasi metrik Strenghts

\begin{tabular}{ccccccc}
\hline $\mathbf{S}$ & $\mathbf{S 1}$ & $\mathbf{S 2}$ & $\mathbf{S 3}$ & $\mathbf{S 4}$ & $\mathbf{S 5}$ & $\begin{array}{c}\text { Rata } \\
\text {-rata }\end{array}$ \\
\hline $\mathbf{S 1}$ & 0,0 & 0,2 & 0,1 & 0,0 & 0,0 & 0,12 \\
& 8 & 6 & 3 & 3 & 9 & \\
$\mathbf{S 2}$ & 0,0 & 0,0 & 0,0 & 0,0 & 0,1 & 0,04 \\
& 1 & 4 & 3 & 2 & 0 & \\
$\mathbf{S 3}$ & 0,0 & 0,2 & 0,1 & 0,2 & 0,1 & 0,15 \\
& 8 & 2 & 3 & 1 & 2 & \\
$\mathbf{S 4}$ & 0,2 & 0,2 & 0,0 & 0,1 & 0,1 & 0,15 \\
& 5 & 2 & 6 & 0 & 0 & \\
$\mathbf{S 5}$ & 0,5 & 0,2 & 0,6 & 0,6 & 0,6 & 0,54 \\
& 8 & 6 & 5 & 3 & 0 & \\
\hline Jumla & 1,0 & 1,0 & 1,0 & 1,0 & 1,0 & 1,00 \\
$\mathbf{h}$ & 0 & 0 & 0 & 0 & 0 & \\
\hline
\end{tabular}

Table 3: Metrik priority vector Weakness

$\begin{array}{llllll}W & W 1 & \text { W2 } & \text { W3 } & \text { W4 } & \text { W5 }\end{array}$

\begin{tabular}{c|ccccc|c}
\hline $\mathbf{W 1}$ & 1 & 5 & 1 & 3 & 3 \\
\hline $\mathbf{W} 2$ & 0,2 & 1 & 1 & 1 & 4 \\
$\mathbf{W 3}$ & 1 & 1 & 1 & 4 & 3 \\
$\mathbf{W 4}$ & 0,33 & 1 & 0,25 & 1 & 4 \\
\hline $\mathbf{W 5}$ & 0,33 & 0,25 & 0,33 & 0,25 & 1 \\
\hline Jumlah & 2,87 & 8,25 & 3,58 & 9,25 & 15 \\
\hline
\end{tabular}


Table 4: Normalisasi metrik Weakness

\begin{tabular}{ccccccc}
\hline $\mathbf{W}$ & $\mathbf{W 1}$ & $\mathbf{W 2}$ & $\mathbf{W 3}$ & $\mathbf{W 4}$ & $\mathbf{W 5}$ & $\begin{array}{c}\text { Rata- } \\
\text { rata }\end{array}$ \\
\hline W1 & 0,35 & 0,61 & 0,28 & 0,32 & 0,20 & 0,35 \\
$\mathbf{W 2}$ & 0,07 & 0,12 & 0,28 & 0,11 & 0,27 & 0,17 \\
$\mathbf{W 3}$ & 0,35 & 0,12 & 0,28 & 0,43 & 0,20 & 0,28 \\
$\mathbf{W 4}$ & 0,12 & 0,12 & 0,07 & 0,11 & 0,27 & 0,14 \\
W5 & 0,12 & 0,03 & 0,09 & 0,03 & 0,07 & 0,07 \\
\hline Jumlah & 1,00 & 1,00 & 1,00 & 1,00 & 1,00 & 1,00 \\
\hline
\end{tabular}

Table 5: Metrik Priority Opportunity

\begin{tabular}{|c|c|c|c|c|c|}
\hline Faktor & 01 & $\mathbf{O 2}$ & $\mathbf{O 3}$ & 04 & 05 \\
\hline 01 & 1 & 5 & 1 & 1 & 0,33 \\
\hline $\mathbf{O 2}$ & 0,2 & 1 & 0,25 & 1 & 0,33 \\
\hline $\mathbf{O 3}$ & 1 & 4 & 1 & 3 & 2 \\
\hline 04 & 1 & 1 & 0,33 & 1 & 0,2 \\
\hline O5 & 3 & 3 & 0,5 & 5 & 1 \\
\hline Jumlah & 6,2 & 14 & 3,08 & 11 & 3,87 \\
\hline
\end{tabular}

Table 6: Normalisasi metrik Opportunity

\begin{tabular}{ccccccc}
\hline $\mathbf{O}$ & $\mathbf{O 1}$ & $\mathbf{O 2}$ & $\mathbf{O 3}$ & $\mathbf{O 4}$ & $\mathbf{O 5}$ & $\begin{array}{c}\text { Rata- } \\
\text { rata }\end{array}$ \\
\hline $\mathbf{O 1}$ & 0,16 & 0,36 & 0,32 & 0,09 & 0,09 & 0,20 \\
$\mathbf{O 2}$ & 0,03 & 0,07 & 0,08 & 0,09 & 0,09 & 0,07 \\
$\mathbf{O 3}$ & 0,16 & 0,29 & 0,32 & 0,27 & 0,52 & 0,31 \\
$\mathbf{O 4}$ & 0,16 & 0,07 & 0,11 & 0,09 & 0,05 & 0,10 \\
$\mathbf{O 5}$ & 0,48 & 0,21 & 0,16 & 0,45 & 0,26 & 0,31 \\
\hline Jumlah & 1,00 & 1,00 & 1,00 & 1,00 & 1,00 & 1,00 \\
\hline
\end{tabular}

Table 7: Metrik priority Treats

\begin{tabular}{cccccc} 
T & T1 & T2 & T3 & T4 & T5 \\
\hline T1 & 1 & 4 & 0,33 & 0,2 & 0,25 \\
T2 & 0,25 & 1 & 0,17 & 1 & 3 \\
\hline
\end{tabular}

\begin{tabular}{cccccc}
\hline T3 & 3 & 6 & 1 & 1 & 2 \\
T4 & 5 & 1 & 1 & 1 & 0,25 \\
T5 & 4 & 0,33 & 0,33 & 4 & 1 \\
\hline Jumlah & 13,25 & 12,33 & 2,83 & 7,2 & 6,5 \\
\hline
\end{tabular}

Table 8: Normalisasi metrik Treats

\begin{tabular}{ccccccc}
\hline T & T1 & T2 & T3 & T4 & T5 & $\begin{array}{l}\text { Rata- } \\
\text { rata }\end{array}$ \\
\hline T1 & 0,08 & 0,32 & 0,12 & 0,03 & 0,04 & 0,12 \\
T2 & 0,02 & 0,08 & 0,06 & 0,14 & 0,46 & 0,15 \\
T3 & 0,23 & 0,49 & 0,35 & 0,14 & 0,31 & 0,30 \\
T4 & 0,38 & 0,08 & 0,35 & 0,14 & 0,04 & 0,20 \\
T5 & 0,30 & 0,03 & 0,12 & 0,56 & 0,15 & 0,23 \\
Jumlah & 1,00 & 1,00 & 1,00 & 1,00 & 1,00 & 1,00 \\
\hline
\end{tabular}

\section{C.3 Penilaian Rating}

Nilai rating berasal dari ekstrenal tata usaha untuk rating IFAS, dan internal tata usaha untuk penilaian rating EFAS. Jumlah responden ditetapkan dengan menggunakan rumus Slovin yaitu

$$
n=\frac{N}{1+\left(N * E^{2}\right)}
$$

Penilaian responden terhadap setiap faktor dijumlahkan menurut kolomnya, kemudian dibagi dengan jumlah responden. Jika hasil bagi terdiri dari pecahan desimal, maka lakukan penyederhanaan bilangan dengan melakukan pembulatan bilangan.

\section{C.4 Tabel IFAS dan EFAS}

Tabel IFAS digunakan untuk mencari kuadran faktor strategi Internal. Kemudian untuk mencari nilai score dengan cara mengalikan nilai bobot dengan nilai rating.

Table 9; Faktor Strategi Internal

\begin{tabular}{lccc}
\multicolumn{1}{c}{ Fable 9; Faktor Strategi Internal } & Bobot & Rating & Score \\
\hline Kekuatan (Strength) & & & \\
Mengunakan Tekhnologi Informasi & 0,14 & 4 & 0,57 \\
\hline Sistem Aplikasi gartis & 0,08 & 4 & 0,31 \\
Mudah melakukan penyimpanan & 0,16 & 4 & 0,62 \\
\hline Tools yang tersedia cukup membantu & 0,15 & 3,67 & 0,56 \\
\hline Mudah dioperasikan oleh hampir semua guru dan pegawai & 0,47 & 3,67 & 1,74 \\
\hline Jumlah & $\mathbf{1 , 0 0}$ & & $\mathbf{3 , 7 9}$ \\
\hline Kelemahan (Weakness) & & & \\
\hline Keterbatasan tenaga & 0,34 & 2,67 & 0,91 \\
\hline Pemrosesan data lambat & 0,18 & 1,67 & 0,31 \\
\hline
\end{tabular}




\begin{tabular}{l|c|c|c}
\hline Prosedur koreksi data nilai tidak efisien & 0,27 & 1,67 & 0,45 \\
\hline Penyimpanan data tidak terstruktur dengan baik & 0,14 & 2 & 0,28 \\
Sering terjadi redudansi data & 0,07 & 2 & 0,13 \\
\hline Jumlah & 1,00 & 2,08 \\
\hline
\end{tabular}

Table 10: Faktor Strategi Eksternal

\begin{tabular}{|lccc}
\hline Faktor faktor Strategi Eksternal & Bobot & Rating & Score \\
\hline Peluang (Opportunity) & & & \\
\hline Dukungan Mudir pondok & 0,21 & 4 & 0,84 \\
\hline Tenaga SDM mudah beradabtasi dengan sistem baru & 0,09 & 3 & 0,28 \\
\hline $\begin{array}{l}\text { Kebijakan memperkenalkan program-program pondok } \\
\text { melalui internet }\end{array}$ & 0,28 & 3 & 0,85 \\
\hline Adanya wacana pembuatan labor komputer & 0,11 & 2 & 0,23 \\
\hline Program depag untuk bantuan TI & 0,30 & 4 & 1,21 \\
\hline Jumlah & $\mathbf{1 , 0}$ & & $\mathbf{3 , 4 0}$ \\
\hline Ancaman (Treats) & & & 0,12 \\
\hline Arus listrik sering terputus & 0,12 & 1 & 0,35 \\
\hline Akses terhadap data tidak terkontrol & 0,17 & 2 & 0,29 \\
\hline Kerusakan dan kehilangan data & 0,29 & 1 & 0,58 \\
\hline Perpindahan virus melalui flashdisch & 0,19 & 2 & 0,44 \\
\hline Lambatnya laporan nilai oleh guru wali kelas & 0,22 & 2 & $\mathbf{1 , 7 8}$ \\
\hline Jumlah & $\mathbf{1 , 0}$ & & \\
\hline
\end{tabular}

\section{C.1 Hasil Analisa SWOT}

Dari hasil analisa, diketahui skor terbesar dari faktor peluang adalah, "Program depag untuk bantuan TI", dengan nilai skor 1,21, dan faktor yang tidak penting adalah wacana pembuatan labor komputer 0,23. Total skor peluang sebesar 3,40.

Sedangkan faktor ancaman dominan dipengaruhi oleh, "Perpindahan virus melalui flashdisch", dengan nilai skor 0,58. Dan masalah arus listrik menjadi ancaman terkecil dengan bobot 0,12 . Total skor ancaman 1,78

Maka dapat diketahui titik kuadran faktor ekternal (sumbu y) dari tabel EFAS adalah jumlah total skor peluang dikurang jumlah total ancaman dibagi dua sama dengan 0,81 .

Selanjutnya pada tabel IFAS dilakukan hal yang sama, dimana pada skor faktor kekuatan didominasi oleh, "Mudah dioperasikan oleh hampir semua guru dan pegawai", sebesar 1,74. Dan faktor, "Sistem Aplikasi gartis" memiliki pengaruh yang paling kecil dengan nilai skor 0,31 . Total skor kekuatan 3,79.

Faktor kelemahan didominasi oleh keterbatasan tenaga kerja pada bagian Tata Usaha dengan skor 0,91. Dan yang paling kecil adalah skor redudansi data 0,13 . Total skor faktor kelemahan adalah 2,08.

Kemudian jumlah skor kekuatan dikurang jumlah skor kelemahan dan dibagi dua, maka didapatkan nilai 0,86 adalah kuadran sumbu $x$ pada matriks SWOT.

Dari analisa diatas dapat diketahui bahwa sumbu $x, y$ berada pada kuadran 0,86 dan 0,81 . Posisi bagian tata usaha mendukung strategi agresif, yaitu dapat melakukan pengembangan pelayanan dengan meningkatkan penggunaan tekhnologi dan sistem aplikasi akademik yang khusus dibuat untuk keperluan dunia pendidikan.

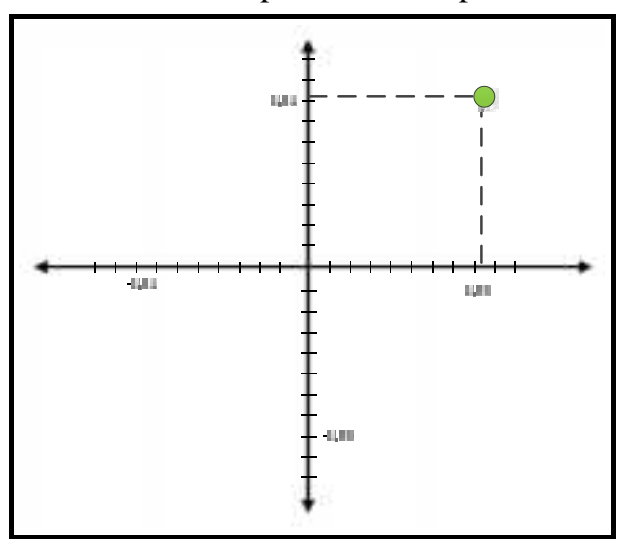

Gambar 1: Kuadran SWOT Bagian Tata Usaha 


\section{Analisa dan Perancangan}

Sistem yang dibangun adalah sistem informasi akademik berbasis web untuk untuk menangani administrasi pada bagian tata usaha dengan hasil akhir berupa printout Laporan Penilaian per semester. Pada tahap ini, dilakukan: (1) analisa sistem yang sedang berjalan; (2) analisa sistem usulan; dan (3) perancangan sistem. Analisa sistem yang sedang berjalan dilakukan dengan cara menganilisis hasil wawancara dan observasi serta dokumen-dokumen yang didapat dari tahap perencanaan. Sedangkan pada tahap analisa sistem usulan dibuat: (1) arsitektur sistem; (2) analisa kebutuhan fungsional sistem; dan (3) aliran data yang terdapat pada sistem. Kebutuhan fungsional dan aliran data secara berturut-turut digambarkan menggunakan usecase diagram dan sequence diagram. Pada tahap perancangan sistem dilakukan pembuatan class diagram, perancangan basis data, perancangan struktur menu serta perancangan antarmuka.

\section{HASIL DAN PEMBAHASAN}

\section{A. Analisa Sistem yang Sedang Berjalan}

Pengolahan data nilai dilakukan dengan menggunakan software Microsoft Office Execel yang sudah umum digunakan diberbagai lembaga dan instansi untuk mengolah data-data noumeric.
Permasalahan data menjadi lambat karena keterbatasan suber daya dan tekhnologi yang digunakan. Contoh, pada proses pengolahan data nilai yang memakan waktu lama hingga musim liburan semester masuk, namun laporan hasil belajar belum dapat dicetak dan dibagikan.

Soal-soal ujian dibuat oleh masing-masing guru bidang studi, kemudian menyetorkannya kepada bagian Tata Usaha, untuk digandakan. Kemudian soal-soal yang sudah digandakan dikembalikan kepada guru bidang studi untuk melaksanakan ujian semester. Hasil ujian diolah guru bidang studi dan dilaporkan pada guru wali kelas. Wali kelas memproses data nilai dan menyerahkannya pada bagian Tata Usaha. Bagian Tata Usaha memproses data nilai menjadi Laporan Hasil Belajar Proses inputan data nilai dilakukan oleh guru wali kelas, kemudian data-data nilai tersebut diolah lagi oleh tata usaha menjadi sebuah Laporan Hasil Pembelajaran semester (raport). Apabila terjadi kesalahan dalam inputan maka harus melakukan kros cek terlebih dahulu kepada guru bidang studinya.

\section{B. Analisa Sistem Usulan}

Untuk merancang sebuah sistem dibuat sebuah flowchart (diagram alir), untuk menggambarkan bagaimana cara kerja sistem dalam membantu menyelesaikan permasalahan. Aliran data pada sistem sistem yang akan dirancang 


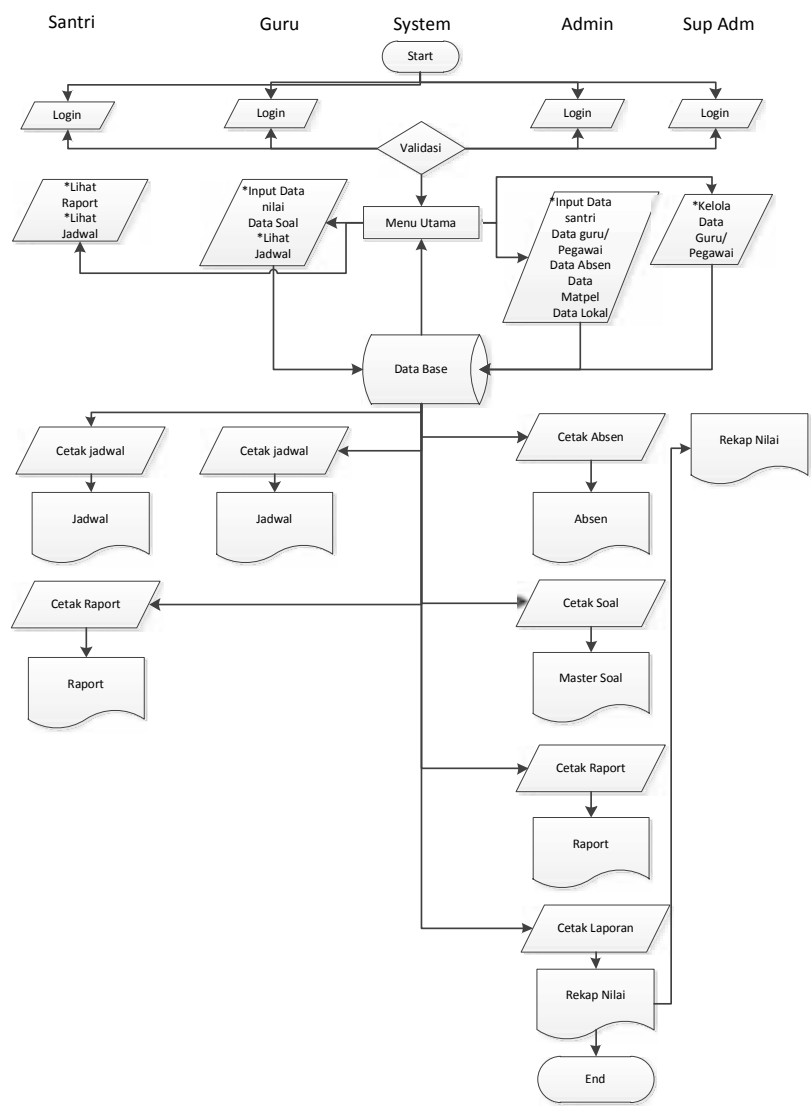

Gambar 2: Flowchart sistem usulan

\section{B.1 Kebutuhan Fungsional Sistem}

Sistem yang dirancang memiliki empat aktor, yaitu super admin, admin, guru dan santri. Kebutuhan fungsional sistem informasi akademik dapat dilihat pada usecase diagram pada Gambar 3.
Aliran data masing-masing usecase yang ada pada usecase diagram digambarkan menggunakan sequence diagram. Gambar 4 merupakan sequence diagram untuk usecase kelola data data oleh admin.

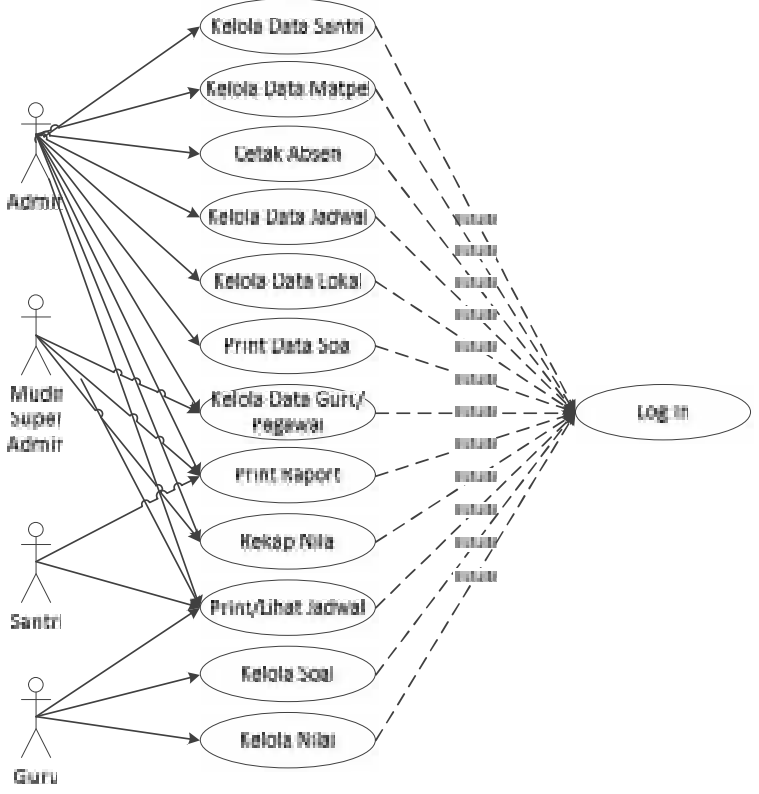

Gambar 3: Use Case Diagram 


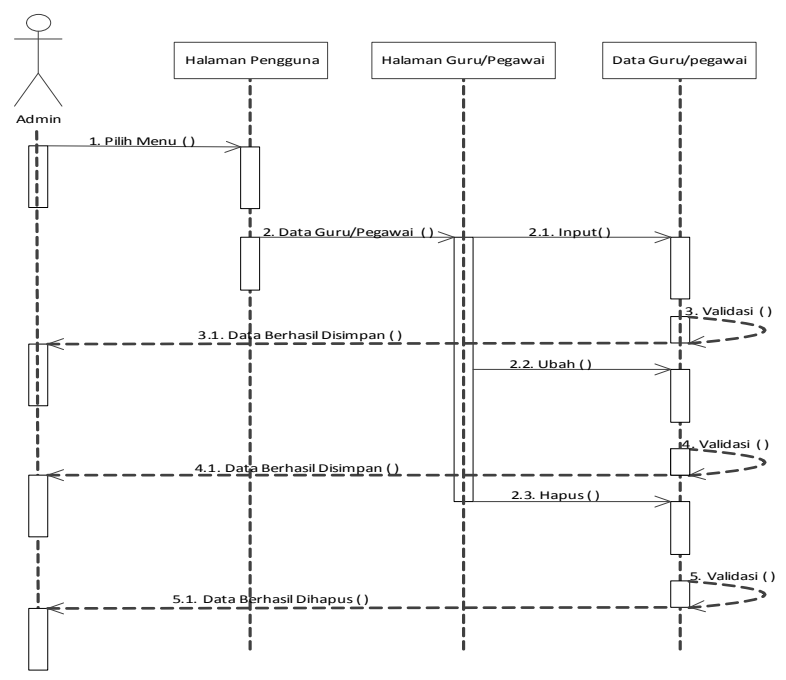

\section{Gambar 4: Sequence Diagram Kelola data oleh admin}

\section{B.2 Perancangan Sistem}

Berdasarkan hasil perancangan, sistem yang dibangun memiliki sepuluh buah class pada class diagramnya. Detail class beserta atribut dan method-nya dapat dilihat pada Gambar 5.

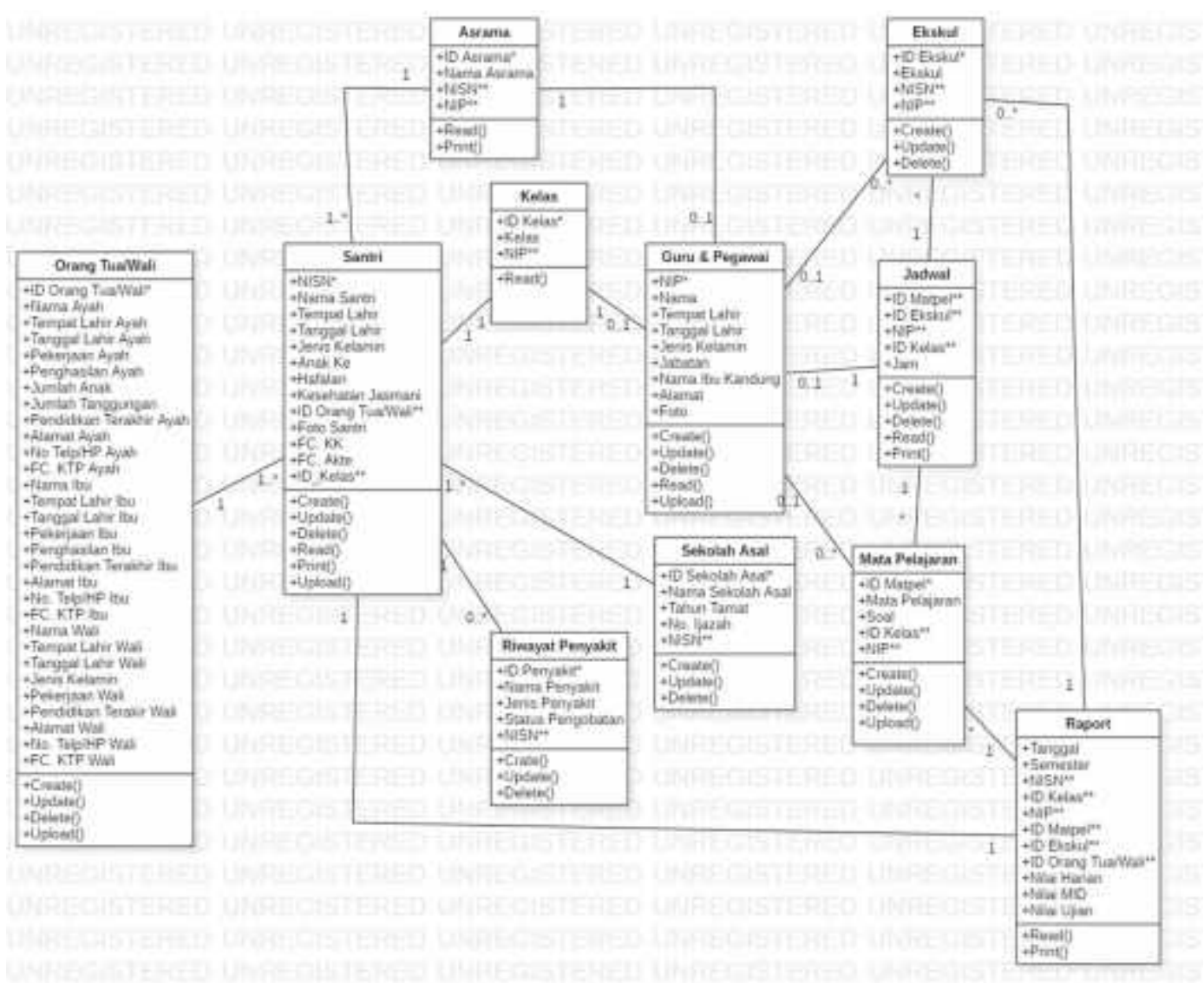

Gambar 5: Class Diagram

\section{B.3 Interface}

Gambaran interface sistem yang akan dibangun dapat dilihat dari berberapa desain 
interface (antar muka) seperti interface login (lih: gambar 6) ini memperlihatkan halaman login yang harus dilalui oleh setiap pengguna, dengan menginputkan username (nama pengguna) dan passwords (kata sandi). Kemudian sistem akan membawa ke halaman pengguna sesuai wewenangnya.

Gambar 7 menunjukan halaman utama admin, pada halaman ini admin dapat memilih menu yang akan digunakannya untuk melakukan pengolahan data crude (Crate, Update, Delete). Pada gambar 8 menunjukan halaman daftar data disimpan.

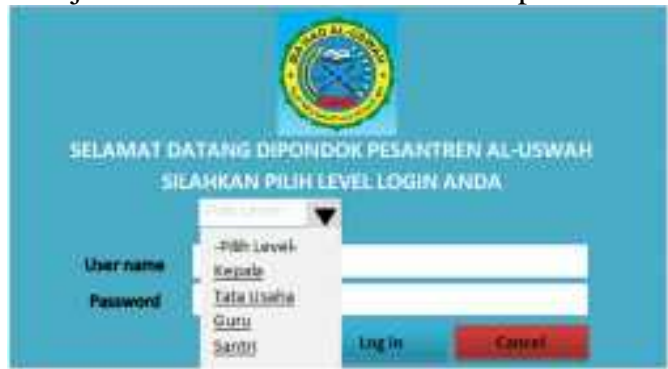

Gambar 6: Interface login

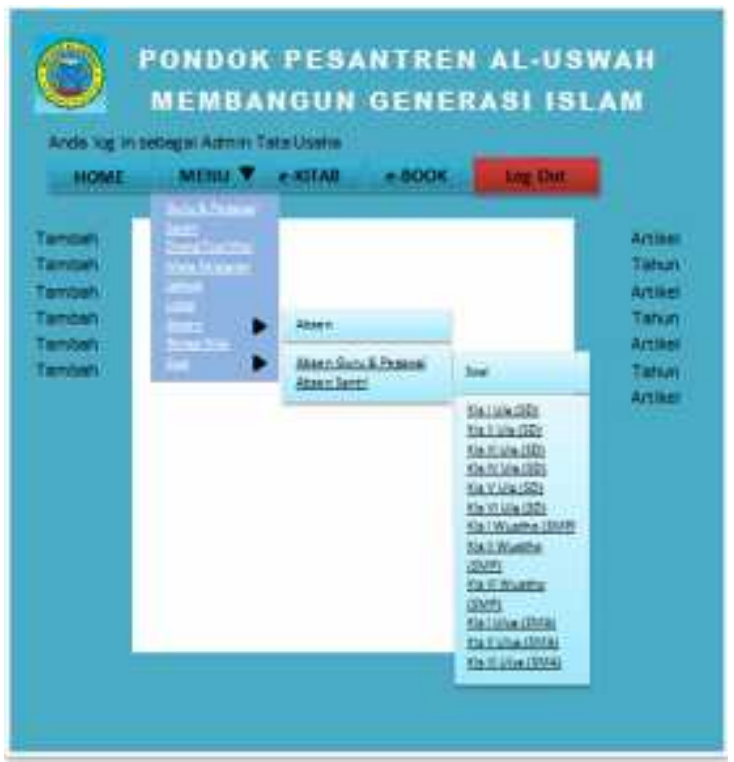

Gambar 7: Interface halaman utama admin

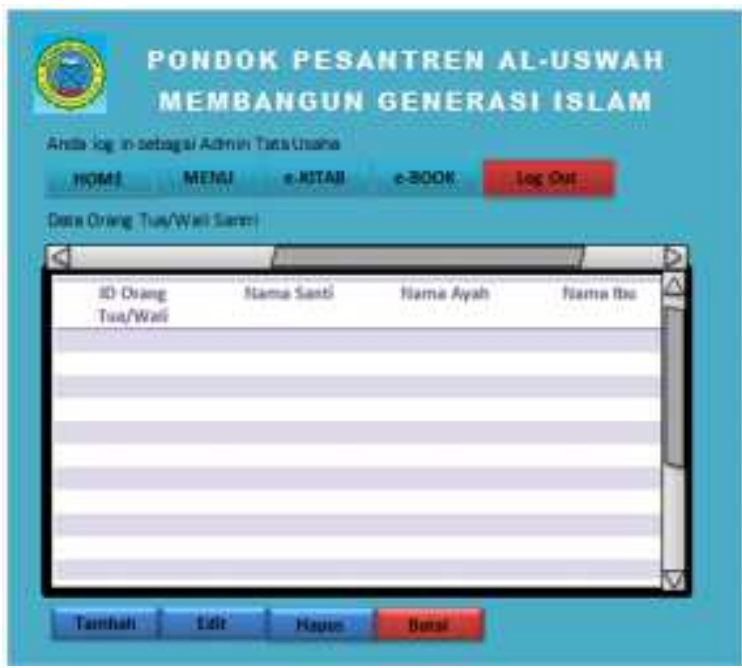

Gambar 8 Daftar list orang tua/wali santri

IV. KESIMPULAN

\section{A. Analisa SWOT}

Hasil analisa SWOT merekomendasikan strategi agresiv, yaitu dengan meningkatkan pelayanan agar dengan memanfaatkan peluang yang ada, mengembangkan sistem informasi menggunakan sebuah aplikasi sistem informasi akademik.

Table 11: Metrik SWOT Bagian tata Usaha Pondok Pesantren Al-Uswah

\begin{tabular}{|c|c|c|}
\hline Internal & Strenghts (S) & Weakness (W) \\
\hline Eksternal & $\begin{array}{ll}\text { - } & \text { Penggunaan Tekhnologi } \\
& \text { Informasi } \\
\text { - } & \text { Sistem Aplikasi gartis } \\
\text { - } & \text { Kemudahan melakukan } \\
& \text { penyimpanan } \\
\text { - } & \text { Tools } \\
\text { - } & \text { Kemampuan SDM } \\
& \text { menggunakan sistem }\end{array}$ & $\begin{array}{ll}\text { - } & \text { Kurangnya tenaga SDM } \\
\text { - } & \text { Lambat melakukan proses data } \\
\text { - } & \text { Prosedur koreksi data nilai } \\
& \text { kurang efektif } \\
\text { - } & \text { Penyimpanan data tidak } \\
& \text { terstruktur dengan baik } \\
\text { - } & \text { Menghindari duplikasi data }\end{array}$ \\
\hline $\begin{array}{l}\text { Opportunities }(\mathrm{O}) \\
-\quad \text { Dukungan Mudir pondok }\end{array}$ & $\begin{array}{c}\text { Strategi SO } \\
\text { Untuk meningkatkan memberikan }\end{array}$ & $\begin{array}{c}\text { Strategi WO } \\
\text { Tenaga SDM bagian tata usaha }\end{array}$ \\
\hline
\end{tabular}


- Adabtasi tenaga dengan sistem performa pelayanan yang lebih

- Kebijakan memperkenalkan program-program pondok melalui internet

- Wacana pembuatan labor komputer

- Program depag untuk bantuan TI

baik bagian tata usaha dapat memanfaatkan dukungan mudir pondok dengan mengunakan dengan jaringan internet.

Penyimpanan data dapat lebih terstruktur sistem informasi yang terkoneksi

Perangkat komputer pada bagian tata usaha hanya digunakan oleh bagian tata usaha, karena ada peluang penambahan unit komputer dalam waktu dekat

\section{Treats $(\mathbf{T})$}

Arus listrik

Kontrol akses data

- Keamanan data terhadap penggunaan ilegal

- Transfer virus melalui flashdhisc

- Kecepatan laporan penilaian guru

\section{Strategi ST}

Pengadaan tenaga listrik cadangan perlu menjadi pertimbangan. Membatasi akses terhadap sistem dengan membuat kunci hak akses Melakukan perpindahan data dengan menggunakan sistem sharing antar komputer yang terkoneksi dengan LAN yang terbatas dapat diatasi dengan penyebaran tugas dan tanggung jawab TU kepada guru. Seperti penginputan nilai dan koreksi nilai dapat dilakukan oleh guru bidang studi.

Menambah jumlah perangkat komputer yang dapat digunakan oleh guru bidang studi untuk meringankan beban kerja bagian tata usaha dengan mengalihkan sebagian tugas dan tanggungjawab bagian tata usaha

\section{Strategi WT}

Mengawasi penggunaan perangkat oleh orang yang tidak berkepentingan

Melakukan transfer data antar komputer hanya dengan menggunakan kabel LAN Menyediakan hak akses terhadap sistem kepada guru sehingga guru bidang studi dapat melakukan input dan koreksi nilai sendiri

\section{B. Analisa Perancangan}

Analisa dan Perancangan Sistem Informasi dibuat sebagai blueprint pengembangan sistem yang dapat memberikan kontribusi untuk meningkatkan mutu pelayanan administrasi. Membantu bagian administrasi atau tata usaha dalam mengelola data pada pondok pesantren aluswah.

Prosedur input data nilai dapat dikurangi dan dilakukan langsung oleh guru bidang studi, sehingga mengurangi kesalahan pengimputan nilai. Seluruh data diasrsipkan secara sistematik dan mudah ditemukan. Akses terhadap data dapat dibatasi menurut wewenang masing-masing user. Sehingga dapat meminimalisir penyalah gunaan data.

\section{REFERENSI}

[1] Amirudin, "KINERJA PEGAWAI TATA

USAHA DENGAN MUTU LAYANAN

ADMINISTRASI DI MADRASAH," vol. VII, no. I, 2017.

[2] F. Rangkuti, Teknik Membedah Kasus Bisnis Analisa SWOT, vol. 22, Jakarta: PT. Gramedia , 2016
[3] S. Shiddiq dan W. M. Pradnya D, "Sistem Informasi Akademik Dan Administrasi Sdit ArRaihan Bantul," Jurnal Ilmiah DASI, vol. 14, no. 04, pp. 49 - 53, 2013.

[4] F. Rangkuti, Analisa SWOT: Teknik Membedah Kasus Bisnis, Jakarta: PT. Gramedia Pustaka Utama, 1997.

[5] R. HM, “ANALISIS SWOT DALAM MENENTUKAN STRATEGI,” vol. 4, no. 1, 2015. 